\title{
Awarding Support Becomes a Dominant Factor in the Election of Family Planning in the Long-Term Contraception Method in Kampung KB
}

\author{
Dewi Ayu NIngsih $^{1 *}$; Firdawati $^{2}$; Pom Harry Satria ${ }^{3}$ \\ 1*) Akademi Kebidanan Panca Bhakti Bandar Lampung \\ 2, Fakultas Kedokteran Universitas Andalas \\ 3 Rumah Sakit Umum Daerah Pariaman Sumatera Barat
}

\section{ARTICLE INFO}

\section{Article history:}

Received April 13, 2019

Revised May 10, 2019

Accepted May 20, 2019

\section{Keyword:}

Psychosocial support

Appraisal Support

Long Acting Reversible Contraceptives

Kampung KB

*) corresponding author

Bagian Kebidanan Akbid Panca Bhakti Bandar Lampung

Email: dewiayu_ningsih@rocketmail.com

DOI:https://doi.org/10.30604/jika.v4i1.185

\begin{abstract}
A B S T R A C T
Indonesia's Maternal Mortality Rate (MMR) is currently in the high category. One effort to reduce MMR is through family planning program. The family planning program contributes in reducing $32 \%$ all of maternal mortality by increasing the coverage of LARC users whose achievements are currently only $17.45 \%$. One of the biggest influences on the escalation of LARC users is psychosocial support from the environment. The objective of this study analyzed the relationship between emotion, informational, instrumental, and appraisal supports from the environment with the LARC use in the Kampung KB. The research used an observational analytic design with a crosssectional approach to 100 respondents that acceptor KB. Statistic analysis used the chi-square and logistic regression. The results of this study showed that the emotional, instrumental and appraisal support were associated with LARC use, based on the $\rho$ values of 0.028, 0.019 and 0,000, respectively. Appraisal support became the dominant factor in choosing LARC in Kampung KB with an odds ratio (OR) 5,000. It meant that a woman who got appraisal support from the environment have 5,000 times higher to have an opportunity to use LARC than the woman who did not get the appraisal support.
\end{abstract}

This is an open access article under the CC-BY-SA license.

\section{INTRODUCTION}

Maternal and child health is a reflection of a country's health development. One of the main indicators of maternal health is the
Maternal Mortality Rate (MMR). AKI in Indonesia is still high at 359 / 100,000 live births (Indonesian Ministry of Health, 2017). 
This figure is far higher compared to the countries in the ASEAN region and the AKI target for Sustainable Development Goals (SDGs) in 2030, which is $70 / 100,000 \mathrm{KH}$ (WHO, 2016). One of the Government's efforts to reduce MMR is through family planning services. Family planning programs can be a strategy in preventing $32 \%$ of all cases of maternal death (Cleland, Bernstein, Ezeh, Faundes, Glasier, \& Innis, 2006).

The percentage of active family planning participants towards couples of childbearing age in Indonesia in 2016 was $74.80 \%$. The three provinces that have the lowest active KB participants are DKI Jakarta (67.46\%), West Sumatra (63.73\%) and East Nusa Tenggara (63.24\%). Achieved by the use of $\mathrm{KB}$ in the Long-Term Contraceptive Method (MKJP) in Indonesia in 2017 is still low at only $17.45 \%$, decreasing from the previous year, which reached $25.99 \%$ and dominated by the injection method $(62.77 \%)$ (RI Ministry of Health, 2017; Indonesian Ministry of Health, 2018). In fact, to successfully reduce MMR, the achievement of MKJP KB use must reach $65 \%$ (Octaviyani, 2017). Not much different, the achievement of the use of MKJP KB in Padang City is also still low as $15.50 \%$ (2016) (Padang City Health Office, 2017) and only slightly increased by $19.00 \%$ in 2017. The condition illustrates that contraceptive use in Kota Padang is dominated by the non MKJP contraceptive use (Padang City Health Office, 2018).

The BKKBN Director of Private KB Participation Development Team revealed that MKJP is the most effective family planning method for spacing pregnancies (Octaviyani, 2017), decreasing birth rates, and increasing family planning participation. The use of MKJP KB is the result of the interaction of various factors, both internal and external factors. The low achievement of MKJP relates to the quality of family planning services, access to family planning services, limited facilities, limited competence of health workers and knowledge of fertile age couples (EFA) towards MKJP. This condition is more prevalent in the regions, which in turn forces the $\mathrm{KB}$ acceptors to prefer the non-MKJP family planning method which is considered more practical (BKKBN, 2016). The role of socialculture, economy, education also plays a big role in the achievement of MKJP (Directorate General of Nutrition and KIA, 2013).

Decision making in choosing a contraceptive method is also influenced by psychosocial support factors from the environment through listening, asking, talking and discuss / negotiate with friends, husband, family, cadres or health workers on contraceptive method choices (Juliastuti, Afiyanti, \& Setyowati, 2008). Taylor's findings revealed that social and emotional support served as a mediator in $81.9 \%$ of contraceptive users with a value of $\rho=0.07$. Someone who always gets social and emotional support is 2.59 times more likely to use contraception than those who never get support (Taylor, 2012). In another study revealed that the role of husbands, health workers and the community have an influence on the low achievement of MKJP (Shodiq, 2016). Other studies report that couples and health workers are a major factor in choosing the MKJP KB method. Lack of support from spouses, lack of decision-making authority, lack of skills of health workers in providing counseling, workload of health workers, client misconceptions about MKJP are the main reasons for inhibiting the use of MKJP family planning (Tebeje B \& Workneh D, 2017). Research conducted by Riyanti reports that $70.3 \%$ of acceptors who use MKJP KB receive psychosocial support from the environment with $\rho=0.001$. The existence of psychosocial support allows 3.97 times someone will use KB MKJP (Riyanti, 2014).

Some of the results of the above research illustrate that psychosocial support from the environment is a factor in the decision to choose to use KB MKJP. Psychosocial support is assistance provided by the social environment in the form of verbal or non- 
verbal information, suggestions, presence and behavior that have an impact on one's emotional and / or behavior (Gottlieb \& Bergen, 2010). The results of the initial survey conducted by interviewing 11 mothers in the Kampung KB area, were found: 4 (four) people used injection $\mathrm{KB}, 1$ (one) person used a pill KB, 1 (one) person used an IUD KB, 2 (two) people used Female Operative Method (MOW), 3 (three) people do not use family planning. This condition shows that only 3 (three) people use MKJP contraception.

This study aims to analyze the correlation of emotional support, informational support, instrumental support and award support with the decision to choose MKJP KB in the Kampung KB of Padang City in 2019. The results of the study are expected to be used as material for evaluation and input for government programs to improve focus family planning services in an effort realize a happy and prosperous family.

\section{METHOD}

This study used an observational analytic design through a cross-sectional approach. The research was carried out in $12 \mathrm{~KB}$ areas in Padang City, namely kampung Penggalangan, Jati Bawah Buluh, Tanah Ombak, Berok Gunung Pangilun, Bangau Putih, Pagang Moderen, Pasa Lalang, Guo, Koto Baru, Kampung Sawah, Lukok and Kampung Baru This research was carried out from the initial survey to the research, namely in August 2018 to January 2019.

The population in this study consisted of 1251 fertile age couples (PUS) active KB acceptors who lived in the KB City area of Padang City. The selection of samples in this study using a simple random sampling technique consisting of 100 EFAs which are active KB acceptors. The dependent variable in this study is the decision to choose $\mathrm{KB}$ MKJP. Meanwhile, the independent variables are emotional support, informational support, instrumental support and award support. The instrument used in collecting research data is a list of questions in the form of a questionnaire consisting of 40 questions. The questionnaire examines the aspects of emotional support, informational, instrumental and rewards obtained by the EFA in the Kampung KB of the City of Padang. In the aspect of emotional support express how much intensity of motivation, compassion, willingness to understand fear, openness to anxiety, willingness to listen to complaints, disappointment, whether or not to ignore what PUS receives when choosing the MKJP method from spouse, family, friends, and family planning officers. In the aspect of informational support, it revealed how much intensity of information, advice or advice obtained by PUS when choosing the MKJP method from the social environment. Furthermore, on the aspect of instrumental support revealing how much intensity of assistance in the form of services, money, goods and facilities obtained by PUS when choosing the MKJP method from the social environment. And finally, the aspect of awarding support reveals how much the intensity of the debate, arguments, attempts to criticize or protest, and permission obtained by PUS by choosing the MKJP method from the social environment. The questionnaire in this study has been tested on 20 respondents who have the same characteristics as the sample in this study. So, the rtable value is 0.444 . After being statistically tested, the 40 questions were declared valid because they had a calculated value> rtable. In line with that, the results of the reliability test calculation state that all questions are repelled because they have a calculated value $\geq$ cronbach alpha value.

Bivariate analysis was conducted to see the correlation between psychosocial support and the decision to choose MKJP KB using the chi-square test. Meanwhile, multivariate analysis was conducted to see the most dominant variables related to the decision to choose MKJP KB using a logistic regression test. 


\section{RESULTS AND DISCUSSION}

Bivariate analysis was conducted to see the correlation between psychosocial support, namely emotional support, informational support, instrumental support and awarding support with the decision to choose MKJP KB in KB City Padang City in 2019. The results of bivariate analysis in this study can be seen in table 1 .

Table 1

The Correlation between Psychosocial Support and Decisions in Choosing MKJP KB in Kampung KB

\begin{tabular}{|c|c|c|c|c|c|c|c|}
\hline \multirow{3}{*}{ Psychosocial support } & \multicolumn{6}{|c|}{ The decision to choose KB MKJP } & \multirow{3}{*}{$\rho$} \\
\hline & \multicolumn{2}{|c|}{ MKJP } & \multicolumn{2}{|c|}{ Non-MKJP } & \multicolumn{2}{|c|}{ Jumlah } & \\
\hline & f & $\%$ & $\mathbf{f}$ & $\%$ & $\mathbf{f}$ & $\%$ & \\
\hline \multicolumn{8}{|l|}{ Emotional support } \\
\hline Good & 28 & 57,14 & 21 & 42,86 & 49 & 100 & \multirow{2}{*}{0,028} \\
\hline Less & 18 & 35,29 & 33 & 64,71 & 51 & 100 & \\
\hline \multicolumn{8}{|l|}{ Informational support } \\
\hline Good & 24 & 47,06 & 27 & 52,94 & 51 & 100 & \multirow{2}{*}{0,828} \\
\hline Less & 22 & 44,90 & 27 & 55,10 & 49 & 100 & \\
\hline \multicolumn{8}{|l|}{ Instrumental support } \\
\hline Good & 32 & 56,14 & 25 & 43,86 & 57 & 100 & \multirow{2}{*}{0,019} \\
\hline Less & 14 & 32,56 & 29 & 67,44 & 43 & 100 & \\
\hline \multicolumn{8}{|l|}{ Appreciate the support } \\
\hline Good & 35 & 62,50 & 21 & 37,50 & 56 & 100 & \multirow{2}{*}{0,000} \\
\hline Less & 11 & 25,00 & 33 & 75,00 & 44 & 100 & \\
\hline
\end{tabular}

Table 1 explains that the respondents who decided to choose MKJP KB were more respondents with good emotional support, namely $57.14 \%$ compared to respondents with less emotional support, namely $35.29 \%$. The difference in numbers is statistically significant with a value of $\rho<0.05$, which means that there is a relationship between emotional support and the decision to choose KB MKJP.

This data shows that the existence of good emotional support from the social environment will have an impact on the PUS decision in choosing to use KB MKJP. The results of this study are in line with the theory that every human being as a social creature has a tendency to be influenced by others in behaving (Suratman, Munir, \& Salamah, 2013). Social support and emotional support are closely related to improving health behavior towards a positive direction. The existence of emotional support from the environment can be a factor in the formation of good health behavior in someone (Strine, Chapman, Balluz, \& Mokdad, 2007).
According to Ucino, the emotional support felt by someone has a positive influence on health physically and psychologically (Thoits, 2011). The results of this study are also in accordance with the research conducted by Muniroh, Luthviatin, \& Istiaji who suggested that the existence of emotional support from the environment, especially from couples would increase the decision of a wife to choose to use KB MKJP (MOW) (Muniroh, Luthviatin, \& Istiaji, 2014).

Furthermore, respondents who decided to choose MKJP KB were more of respondents with good informational support, namely $47.06 \%$ compared to respondents with less informational support, namely $44.90 \%$. The difference in numbers is not statistically significant with a value of $\rho>0.05$, which means that there is no relationship between informational support and the decision to choose KB MKJP. Although in distribution, respondents who decided to use MKJP KB were more of respondents with good 
informational support compared to respondents with less informational support. The data describe that information, support obtained by respondents from the surrounding environment such as spouse, family, neighbors, and health workers is not directly related to the respondent's decision in choosing the MKJP KB method. Statistically, the results of this study are not related to the possibility caused by developments in the world of technology in society that have an impact on the increasing development of information media such as electronic media, namely radio, television, smartphone and ease of access to the internet. These media are good alternatives in obtaining information related to the MKJP KB method. Glanz, Rimer, \& Viswanath revealed that the provision of social support, especially information, support, must be given interpersonally, in which there is concern, trust, and respect for one's rights in deciding their choices (Glanz, Rimer, \& Viswanath, 2008). The results of this study are in line with the research conducted by Mahmudah and Indrawati where respondents who have received counseling, information and education (IEC) related to the KB method mostly decide to use non-MKJP family planning, namely $37.50 \%$ compared to respondents who choose to use the method MKJP KB is $26.92 \%$ (21) (Mahmudah \& Indrawati, 2015).

Furthermore, respondents who decided to choose MKJP KB were more respondents with good instrumental support of $56.14 \%$ compared to respondents with less instrumental support which was $32.56 \%$. The difference in numbers is statistically significant with a value of $\rho<0.05$, which means that there is a relationship between instrumental support and the decision to choose KB MKJP.

This data shows that the presence of good instrumental support from the social environment will have an impact on the PUS decision in choosing to use KB MKJP. Forms of instrumental support can be in the form of assistance directly in accordance with the needs of the subject, especially in the availability of goods (material) or services of others that can be used by the subject in overcoming the problem (Glanz, Rimer, \& Viswanath, 2008). Forms of instrumental support, especially those for couples, can be in the form of material or direct assistance such as facilitating financing problems or participating in delivering their wives to get MKJP KB services (MOW) in Health Facilities (Muniroh, Luthviatin, \& Istiaji, 2014). The research conducted by Setiasih, Widjanarko, estate is in line with the results of the above study, where they prove a significant relationship between the availability of family planning services and the PUS decision to choose a non-hormonal MKJP KB method with a value of 0.011 (Setiasih, Widjanarko, \& Istiar, 2016).

The results of this study are also in line with the research conducted by Murphy, Stoffel, Nolan, \& Haider, who found that instrumental support in MKJP family planning services is a factor that influences acceptance or rejection of MKJP KB methods in adolescents (Murphy, Stoffel, Nolan, \& Haider, 2016).

Finally, the respondents who decided to choose MKJP KB were more respondents with good appreciation, support, which was $62.50 \%$ compared to respondents with less appreciation support, namely $25.00 \%$. The difference in numbers is statistically significant with a value of $\rho<0.05$, which means that there is a relationship between the support of the award and the decision to choose KB MKJP.

This data shows that the existence of good awarding support from the social environment will have an impact on the PUS decision to choose to use KB MKJP. In his research, Muniroh, Luthviatin, \& Istiaji revealed that the award support obtained by someone could be an expression of respect for the decisions taken, encouragement to increase self-confidence to be more advanced, and help someone to see the positive aspects in him to be compared with others who function to increase self-esteem 
and approval of individual ideas or feelings. In the analysis conducted by the three researchers, information was obtained that most couples (husbands) gave award support in the form of approval to their wives to use the MKJP KB method (MOW) (Muniroh, Luthviatin, \& Istiaji, 2014). The results of this study in accordance with the research conducted by Sulastri \& Nirmasari found that most husbands gave appreciation to their wives for using the IUD family planning through the participation of husbands in consulting and choosing contraception (Sulastri \& Nirmasari, 2014).

Multivariate analysis in this study aims to determine which independent variables are mostly related to the decision to choose $\mathrm{KB}$ MKJP on respondents. Multivariate modeling was carried out by multiple logistic analysis of variables that had fulfilled the requirements to enter into multivariate modeling, namely emotional support variables, instrumental support and award support. The results of the multiple logistic analysis can be seen in the table below 2 .

Table 2

Results of Multivariate Modeling Analysis

\begin{tabular}{cccccccc}
\hline Tahapan & Variable & B & SE & Wald & o & OR & $\begin{array}{c}\text { Echange OR } \\
(\%)\end{array}$ \\
\hline Full Model & Emotional Support & $-0,094$ & 0,557 & 0,029 & $0,866^{*}$ & 0,910 & \\
& Instrumental support & 0,887 & 0,535 & 2,752 & 0,097 & 2,428 & \\
& Appreciation support & $-3,169$ & 0,923 & 11,776 & 0,001 & 4,775 & \\
\hline Step I & Instrumental support & 0,838 & 0,449 & 3,486 & $0,062^{*}$ & 2,312 & 4,778 \\
& Appreciation support & 1,532 & 0,452 & 11,476 & 0,001 & 4,628 & 3,079 \\
\hline Step II & Appreciation support & 1,609 & 0,444 & 13,122 & 0,000 & 5,000 & 4,712 \\
\hline
\end{tabular}

* Excluded at a later stage.

Table 2 shows that the dominant variable associated with the decision to choose MKJP $\mathrm{KB}$ in KB City of Padang is award support with an OR value of 5,000 which means that EFA that has good award support will be 5,000 times more likely to decide to choose MKJP family planning as the contraceptive method to use. Award support is an important aspect in building one's confidence in solving problems or behaving. Award support is closely related to aspects of emotional, informational and instrumental support where generally it aims to help towards positive behavior (Glanz, Rimer, \& Viswanath, 2008).

\section{CONCLUSIONS AND RECOMMENDATION}

Based on the results and discussion above, it can be concluded that there is a significant correlation between emotional support, instrumental support, and award support with the decision to choose MKJP KB in Kampung KB in 2019. Award support is the dominant factor that influences EFA to choose MKJP family planning in the Kampung KB in 2019.

Suggestions for further research to analyze the relationship of the workload of officers recording and reporting on the quality of MKJP KB counseling in first-level Health Facilities. Deepening the analysis of factors related to the presence of awarding support for the use of the MKJP method. 


\section{REFERENCES}

BKKBN. (2016). Laporan Kinerja Instansi Pemerintah $2015 \quad$ Badan Kependudukan dan Keluarga Berencana Nasional. Jakarta: BKKBN. Retrieve from : https://www.bkkbn.go.id/pocontent/uploads/LAKIP_BKKBN_201 6.pdf

Cleland, J., Bernstein, S., Ezeh, A., Faundes, A., Glasier, A., \& Innis, J. (2006). Family planning: the unfi nished agenda. Lancet, Vol.368, Hal. 181027. https://doi.org/10.1016/S01406736(06)69480-4

Dinas Kesehatan Kota Padang. (2017). Profil Kesehatan Kota Padang Tahun 2016. Padang: Dinkes Kota Padang. Retrieve from

https://dinkes.padang.go.id/read/191-

Profil_Kesehatan_Kota_Padang Tahu n 2016

Dinas Kesehatan Kota Padang. (2018). Profil Kesehatan Kota Padang Tahun 2017. Padang: Dinas Kesehatan Kota Padang. Retrieve from : https://dinkes.padang.go.id/read/230Profil_Kesehatan_Kota_Padang_Tahu n_2018 Data_Tahun_2017

Direktorat Jenderal Bina Gizi dan KIA. (2013 ). Rencana Aksi Nasional Pelayanan Keluarga Berencana 2014-2015. Jakarta: Kemenkes RI. Retrieve from : https://indonesia.unfpa.org/sites/defaul t/files/pub-pdf/RAN-PELAYANAN$\underline{\text { KB.pdf }}$

Glanz, K., Rimer, B. K., \& Viswanath, K. (2008). Health Behavior and Health Education Theory, Research, and Practice Fourth Edition. United States of America: Jossey-Bass. Retrieve from

https://www.worldcat.org/title/healthbehavior-and-health-education-theoryresearch-and-practice/oclc/225874161
Gottlieb, B., \& Bergen, A. (2010). Social Support Concept and Measures. Journal of Psychosomatic Research, Vol. $69 . \quad$ Hal. 511-520. https://doi.org/10.1016/j.jpsychores.20 $\underline{09.10 .001}$

Juliastuti, D., Afiyanti, Y., \& Setyowati. (2008). Pengambilan Keputusan Pemakaian Kontrasepsi Ibu Grande Multopara Di Kabupaten Tangerang : Study Grounded Theory. Jurnal Keperawatan Indonesia, Vol. 12, No. 2, Hal. 100-107. Retrieve from : https://www.researchgate.net/publicati on/321124522

Kemenkes RI. (2017). Profil Kesehatan Indonesia Tahun 2016. Jakarta: Kemenkes RI. Retrieve from : http://www.depkes.go.id/resources/do wnload/pusdatin/profil-kesehatanindonesia/Profil-Kesehatan-Indonesia2016.pdf?opwvc $=1$

Kemenkes RI. (2018). Profil Kesehatan Indonesia Tahun 2017. Jakarta: Kemenkes RI. Retrieve from : http://www.depkes.go.id/resources/do wnload/pusdatin/profil-kesehatanindonesia/Profil-Kesehatan-Indonesiatahun-2017.pdf

Mahmudah, L., \& Indrawati , F. (2015). Analisis Faktor yang Berhubungan dengan PemilihanMetode Kontrasepsi Jangka Panjang (MKJP) pada Akseptor KB Wanitadi Kecamatan Banyubiru Kabupaten Semarang. Unnes Journal of Public Health, Vol. 2, Hal. 76-85. DOI:

https://doi.org/10.15294/ujph.v4i3.722 $\underline{2}$

Muniroh, I., Luthviatin, N., \& Istiaji , E. (2014). Dukungan Sosial Suami Terhadap Istri untuk Menggunakan Alat Kontrasepsi Medis Operasi Wanita (MOW) (Studi Kualitatif pada Pasangan Usia Subur Unmet Need di Kecamatan Puger Kabupaten Jember) . e-Jurnal Pustaka Kesehatan, Vol.2, 
No.1, hal. 66-71. Retrieve from : https://jurnal.unej.ac.id/index.php/JPK/ article/view/598

Murphy, M., Stoffel, C., Nolan, M., \& Haider, S. (2016). Interdependent Barriers to Providing Adolescents with Long-Acting Reversible Contraception: Qualitative Insights from Providers. Journal of Pediatric and Adolescent Gynecology, Volume. 29, Pages 436-442. https://doi.org/10.1016/j.jpag.2016.01. $\underline{125}$

Octaviyani, P. R. (2017). KB Jangka Panjang Minim. Diakses pada tanggal 15 Mei 2018:

http://www.mediaindonesia.com/read/ detail/136893-kb-jangka-panjangminim. Retrieve from : http://www.mediaindonesia.com/read/ detail/136893-kb-jangka-panjangminim

Riyanti. (2014). Pengetahuan, Psikososial, Dan Motivasi Ibu Peserta KB Metode Kontrasepsi Jangka Panjang di Kota Palangka Raya . Jurnal Forum Kesehatan, Vol. IV, No. 7. Retrieve from

https://docplayer.info/29546407Pengetahuan-psikososial-dan-motivasiibu-peserta-kb-metode-kontrasepsijangka-panjang-di-kota-palangkaraya.html

Setiasih, S., Widjanarko, B., \& Istiar, T. (2016). Analisis Faktor-faktor yang Mempengaruhi Pemilihan Metode Kontrasepsi Jangka Panjang (MKJP) pada Wanita Pasangan Usia Subur (PUS) di Kabupaten Kendal Tahun 2013 . Jurnal Promosi Kesehatan Indonesia , Vol. 11, No. 2, Hal. 32-46. Retrieve from https://ejournal.undip.ac.id/index.php/i pki/article/download/19002/13247

Shodiq, M. (2016). Faktor yang Mempengaruhi Kesertaan KB Melalui Metode Kontrasepsi Jangka Panjang
(MKJP) Di Kabupaten Tulang Bawang Barat. Jakarta: Prosiding Pertemuan Ilmiah Ikatan Widyaiswara Indonesia, Rapat Kerja Nasional Pengurus Pusat. Retrieve from https://www.scribd.com/doc/31244023 8/Faktor-Yang-Mempengaruhi$\underline{\text { Rendahnya-KB-MKJP }}$

Strine , T., Chapman , D., Balluz, L., \& Mokdad , A. (2007). Health-related Quality of Life and Health Behaviors by Social and Emotional Support Their Relevance to Psychiatry and Medicine. Soc Psychiatry Psychiatr Epidemiol, DOI https://doi.org/10.1007/s00127007-0277-x. Retrieve from : : https://www.researchgate.net/publicati on/5882864

Sulastri, S., \& Nirmasari, C. (2014). Hubungan Dukungan Suami dengan Minat Ibu dalam Pemakaian Kontrasepsi IUD di Bergas. https://jurnal.unimus.ac.id/index.php/p sn12012010/article/view/1418, Hal. 44-49.

Suratman, Munir, \& Salamah, U. (2013). Ilmu Sosial dan Budaya Dasar. Malang: Intimedia.

Taylor, J. A. (2012). Sicial Support As A Mediator of Demographic Disparities in Contraceptive Use Among U.S Women. Disertasi. The University of Alabama: Alabama. Retrieve from : https://ir.ua.edu/bitstream/handle/1234 56789/1404/file_1.pdf?sequence $=1 \&$ is Allowed $=\mathrm{y}$

Tebeje B, \& Workneh D. (2017). Prevalence, Perceptions and Factors Contributing to Long Acting Reversible Contraception Use among Family Planning Clients, Jimma Town, Oromiya Region, South-West Ethiopia - Journal of Women's Health Care, Volume 6. Hal. 1-10. https://doi.org/10.4172/2167$\underline{0420.1000351}$ 
J urnal Aisyah: J urnal Ilmu Kesehatan, 4(1), Juni 2019, - 81

Dewi Ayu NIngsih; Firdawati; Pom Harry Satria

Thoits , P. (2011). Mechanisms Linking Social Ties and Support ti Physical and Mental Health. Journal of Health and Social Behavior, 52 (2), Hal. 145 -161. Retriev from

http://hsb.sagepub.com/content/52/2/1 $\underline{45}$
WHO. (2016). World Health Statistics 2016: Monitoring Health for the SDGs. France: WHO. Retriev from : https://www.who.int/gho/publications/ world_health_statistics/2016/en/ 